\title{
Rudolf Bultmann oor die opstanding van Jesus
}

\author{
G M M Pelser \\ Departement Nuwe-Testamentiese Wetenskap (Afd A) \\ Universiteit van Pretoria
}

\begin{abstract}
Rudolf Bultmann on the resurrection of Jesus

The findings of the Jesus Seminar in the USA regarding the resurrection of Jesus as well as the fairly recent (1994) publication of Gerd Lüdemann's book on the resurrection of Jesus prompted this investigation into Bultmann's thoughts on the resurrection of Jesus. The reason for investigating Bultmann's thoughts lies in the fact that both the Seminar's and Lüdemann's findings correspond in one way or another to with what Bultmann already contended more than fifty years ago, although their approaches with regard to the role and significance of historical investigation differ considerably in certain respects. This essay focuses on the following aspects of Bultmann's approach: the resurrection as expression of the significance of the cross; the unhistorical character of the resurrection (i.e. not the resuscitation of Jesus' corpse); the resurrection as eschatological event; the question as to the nature of the appearances of the risen Jesus; Jesus as risen in the kerygma; faith as the only way of experiencing the risen Lord, and, finally, one's own resurrection to a new existence in the Lord.
\end{abstract}

\section{INLEIDING}

Dit is betreklik wyd bekend dat die resultate van die navorsing wat die Jesus Seminar van die Westar Institute in die Verenigde State van Amerika die afgelope bykans twee dekades oor die historiese Jesus gedoen het, aansienlike beroering in bepaalde teologiese en kerklike kringe veroorsaak het. Dit geld nie alleen die reduksie wat hierdie navorsing ten gevolg gehad het wat betref die Jesuslogia nie, maar veral ook wat betref die Jesushandelinge, en by name die opstanding van Jesus. Hierby kan gevoeg word die boek van Gerd Lüdemann (1994) oor Jesus se opstanding wat vir sy eie kwota aan opskudding gesorg het. Hierdie verwikkeling het dit onvermydelik gemaak dat oral waar erns gemaak word met die Nuwe-Testamentiese getuienis oor Jesus, daar opnuut oor die vraag na Jesus se opstanding besin moes word, en dit vanselfsprekend omrede 
die opstanding van Jesus van die vroegste tye af so 'n fundamentele en sentrale plek in die verkondiging, teologie en geloofslewe van die Christelike kerk ingeneem het. Die resultate van die werk van die Jesus Seminar was egter ook in verskeie opsigte 'n herinnering aan en bevestiging van die uitsprake wat Bultmann reeds meer as vyftig jaar gelede oor dieselfde onderwerp gemaak het en wat tó́ net soos nóú in die geval van die Jesus Seminar vir baie verontrustend was.

Soos dit ten opsigte van heelwat van die ander teologiese standpunte van Bultmann die geval was, is hy dikwels ook in hierdie verband heeltemal of gedeeltelik misverstaan. En soos in die ander gevalle moet die feit dat hy ook in hierdie geval misverstaan is, ' $n$ mens nie te veel verbaas nie, aangesien dit meermale 'n baie noukeurige lees van sy gedagtes verg om werklik agter die kap van die byl te kom. Ook in hierdie geval was daar dus mense wat hom verkeerd verstaan het, nie soseer omdat hulle hom uit die staanspoor as ' $n$ ketter beskou het nie, dit natuurlik ook, maar omdat hulle nie die moeite gedoen het om agter te kom wat hy probeer sê het nie. Hulle het hom óf nie self gelees nie óf wanneer hulle hom wel gelees het, het hulle hom nie noukeurig gelees of sy uitsprake probeer verstaan teen die agtergrond van sy teologiese denke in die algemeen en die eksistensiale aspek daarvan in die besonder nie.

Wie reeds in 'n redelike mate van Bultmann se denke kennis geneem het, sal weet dat hy hom betreklik uitvoerig oor die opstanding van Jesus uitgelaat het veral in sy opstel Neues Testament und Mythologie (kyk Bultmann 1948a) waarmee hy in 1941 sy ontmitologiseringsprogram ingelui het, en in ' $n$ mindere mate in sy Theologie des Neuen Testaments (kyk Bultmann 1968a) en 'n paar opstelle. Ek maak nie daarop aanspraak dat ek daarin geslaag het om alles wat hy oor die onderhawige onderwerp gesê het, in hierdie opstel byeen te bring nie. Ek meen egter dat die essensie van sy denke tog hierin weergegee word, selfs in die gevalle waar ek hom nie direk aanhaal nie maar sy gedagtes min of meer in vertaalde vorm of opsommerderwys weergee. In wat hier volg, gaan ek probeer om sy gedagtes so samehangend as moontlik weer te gee, sonder egter om daarmee te wil voorgee dat ek hom op elke punt reg verstaan of in alle opsigte aan sy opvattings oor die saak reg laat geskied. Deur sy uitsprake onder bepaalde rubrieke aan die orde te stel, het ek reliëf probeer gee aan die verskillende fasette wat daar in sy denke te bespeur is. Dit is onvermydelik dat daar soms herhaal word. Die rede hiervoor is dat van die uitsprake so geformuleer is dat dit by meer as een denkkategorie ter sake is. Ek vertrou egter dat wat ek aanbied, so georden en weergegee word dat dit beide aan Bultmann sal reg laat geskied en vir die leser 'n koherente beeld van sy denke sal gee. 
Die primêre oogmerk met hierdie opstel is om Bultmann se gedagtes oor Jesus se opstanding te probeer saamvat en nie soseer om ' $n$ indringende bespreking daarvan te onderneem nie. Nogtans gaan ek in bepaalde gevalle aandag gee aan reaksie en kommentaar op Bultmann en waar nodig geag, self 'n paar opmerkings maak.

\section{SLEGS UITDRUKKING VAN DIE BETEKENIS VAN DIE KRUIS}

\subsection{Uitdrukking van die betekenis van die kruis}

Dit is Bultmann se oortuiging dat die spreke oor (Rede von) die opstanding van Christus nie anders verstaan kan word as dat dit die uitdrukking van die betekenis van die kruis is nie, naamlik dat die kruisdood van Jesus nie as 'n menslike sterwe opgevat moet word nie, maar as God se bevrydende gerig oor die wêreld, die gerig wat as sodanig die dood sy mag ontneem het (Bultmann 1948a:47-48; kyk ook Bultmann 1958a:207-208). Is dit, vra Bultmann (1948a:48), nie juis hierdie waarheid wat uitgedruk word in die stelling dat die gestorwene nie in die dood gebly het nie maar opgestaan het?

\subsection{Kruis en opstanding 'n eenheid}

Kruis en opstanding vorm derhalwe as 'kosmiese' gebeure 'n eenheid. Dit beteken dat dit nie so verstaan moet word dat die kruisgebeure die dood en ondergang van Jesus was waarop die opstanding toe as 'n herroeping van die dood gevolg het nie (Bultmann 1948a:48). Dat kruis en opstanding 'n eenheid is, is ook daarin geleë dat albei eskatologiese gebeurtenisse is. 'So ist auch, was am Kreuz und zu Ostern geschah, zweierlei nur sub specie der menschlichen Zeitlichkeit, nicht als eschatologisches Geschehen' (Bultmann 1948b:144). Volgens Bultmannn vind ons hier, soos ook ten opsigte van ander sake in verband met Jesus, 'n eienaardige ineengestrengeldheid van die historiese en die mitiese: naas die historiese gebeurtenis van die kruis staan naamlik die opstanding wat nie 'n historiese gebeurtenis was nie (Bultmann 1948a:44). Kay interpreteer Bultmann in hierdie verband reg wanneer hy daarop wys dat soteriologies gesproke hierdie eenheid nie dié is van die opeenvolging van twee naby mekaar liggende historiese gebeurtenisse van die verlede nie, maar die gelyktydige eenheid van 'n historiese gebeurtenis (die kruis) en sy kontemporêre eksistensiale betekenis (die opstanding; Kay 1994:105).

Die rede waarom die opstanding volgens Bultmann nie gesien moet word as 'n herroeping van die dood en ondergang van Jesus wat aan die kruis sou plaasgevind het nie, is omdat Hý wat die dood ervaar het, reeds die Seun van God was en dat sy dood self 
reeds die oorwinning oor die mag van die dood was. Hierdie oorwinning het dus nie eers met sy opstanding plaasgevind nie (Bultmann 1948a:48). Hieroor het Schmithals met klaarblyklike instemming opgemerk dat paradoksaal gestel, 'n mens kan sê dat dit die 'Opgestane' is wat aan die kruis gesterf het (Schmithals 1967:141). Dit alles beteken egter nie dat die opstanding deur Bultmann ontken of van alle betekenis gestroop word nie. Daarom het die Evangelisch-theologische Fakultät der Universität Tübingen (=EthFUT) in sy rapport tereg daarop gewys dat dit verkeerd is om dit voor Bultmann se deur te lê dat hy die belydenis van Jesus as die opgestane wou skrap. Waarom dit vir hom gegaan het, is dat die opstanding nie verstaan kan word as 'n feit wat van die kruis losgemaak kan word en waarvan die werklikheid bewys kan word buite die geloof om nie. Dit wil sê, indien die verkondiging van die Opgestane in dié sin naas dié van die Gekruisigde sou tree dat die kruis daarmee so te sê sy betekenis verloor en slegs nog as die donker agtergrond van die opstanding dien, sal 'n mens by die beslissende van die gebeure verbygaan. Die opwekking van Christus is volgens hierdie beskouing die Goddelike 'ja' vir die kruis, en die verkondiging van die Opgestane sê dat in die woord van die kruis Jesus Christus as die gekrụisigde teenwoordig is en juis só teenwoordig is as die oorwinnaar oor sonde en dood. Dit alles kom daarop neer dat daar op Paassondag nie gepreek moet word as sou Goeie Vrydag 'n verbygegane iets wees nie, en dat omgekeerd op Goeie Vrydag nie gepreek moet word asof 'n mens niks van Pase weet nie (EthFUT 1952:35).

\subsection{Nie 'n verifiërende mirakel nie}

Kruis en opstanding vorm 'n eenheid omdat hulle saam die een kosmiese gebeurtenis is waardeur die wêreld gerig en die moontlikheid van egte lewe geskep is. Om hierdie rede kan die opstanding nie ' $n$ verifiërende mirakel wees waarvan die vasstelbare sekerheid veronderstel is om te dien as 'n bewys dat die kruis werklik die kosmies-eskatologiese betekenis het wat daaraan toegeskryf word nie (Bultmann 1948a:48). Die ware Paasgeloof is die geloof wat glo dat Jesus na God toe opgevaar het 'und so den Anstoß des Kreuzes verstehend besteht; er ist nicht der Glaube an eine greifbare innerweltliche Demonstration des Auferstandenen' (Bultmann 1968b:533). Om te verstaan wat Bultmann hiermee bedoel, moet ' $n$ mens bekend wees met sy definisie van Mirakel en veral met die onderskeid wat hy maak tussen mirakel en Wunder. In aansluiting by die gangbare definisie van mirakel stel hy dat daar van 'n mirakel eerder as van 'n 'wonder' sprake is wanneer onder wonder 
nur noch ein über- oder gegennatürliches Ereignis verstanden wird, das man freilich auf Gott zurückführt, jedoch so, daß man Gott dabei nur als den übernatürlichen Verursacher denkt, ohne das Ereignis als solches als Gottes Tat zu verstehen; man behält dann nur den Gedanken des Mirakels.

(Bultmann 1958c:214)

Waarom dit dus basies vir Bultmann gaan, is dat wanneer aan 'n wonder gedink of daaroor gepraat word as sou dit die deurbreking wees van die wetmatigheid van die natuur, dit in werklikheid nie 'n wonder is wat ter sprake is nie maar 'n mirakel. 'n Mirakel word dan ook altyd veronderstel 'n objektief waarneembare en demonstratiewe gebeure te wees met sensasionele karakter. Hierdie 'mirakel'-opvatting van wat 'n wonder is, kan ons volgens Bultmann nie meer deel nie en moet prysgegee word, aangesien 'n mens met so 'n opvatting die gedagte prysgee dat 'n wonder die werk van God is (Bultmann 1958c:216). Hierteenoor staan die wonder wat as daad van God 'n verborge saak is en nie anders as deur 'n wonder herken kan word nie. Dit is 'in keinem Sinne ein irgendwo und irgendwie konstatierbares Ereignis in der Welt' (Bultmann 1958c:219-220). Dit kan derhalwe nie dien as 'n konstateerbare gebeurtenis wat die geloof in God moet begrond en 'n mens tot die slotsom moet bring dat God bestaan (en handel) nie. Die wonder is as wonder verborge vir dié wat nie vir God daarin sien nie (Bultmann 1958c:220). Wat dit inhou, is dat om van 'n wonder te praat, dieselfde is as om van my eie eksistensie te praat, dit wil sê daarvan te praat dat God in my lewe sigbaar geword het. Dit gaan egter nie om 'n algemene sigbaarheid van God nie, maar om sy openbaring. Daar is dus net een wonder: die wonder van die openbaring. Dit is die openbaring van God se genade vir die goddelose, die openbaring van sy vergifnis (Bultmann 1958c:221). In hierdie sin sou dan ook van Christus se kruis en opstanding as 'n wonder gepraat kan word.

Volgens Bultmann is die opstanding van Jesus meermale in die Nuwe Testament as so 'n verifiërende mirakel opgevat. As voorbeelde hiervan verwys hy na die outeur van Handelinge se oortuiging dat God die legitimiteit van Jesus se aansprake deur sy opstanding bewys het (Hand 17:31), en na die legende van die leë graf en die Paasvertellings wat bedoel is om daaraan uitdrukking te gee dat Jesus liggaamlik opgestaan het (veral Luk 24:39-43). Ons het hier sonder twyfel te doen met latere konstruksies waarvan Paulus nog niks geweet het nie. Paulus het wel ook eenmaal probeer om deur die opnoem van ooggetuies (1 Kor 15:3-8) die opstanding as historiese gebeurtenis seker te stel (Bultmann 1948a:48; 1958a:207). Dit was egter fataal om hiermee 'n bewys vir die geloofwaardigheid van die kerugma te wou aanvoer (Bultmann 1948b: 
144). Hoe fataal hierdie soort argumentasie is, is volgens Bultmann selfs deur Barth téén sy sin erken toe hy geoordeel het dat Paulus hiermee nie die opstanding as 'n historiese feit wou bewys nie, maar bloot wou sê dat ook hý soos die vroegste gemeente Jesus as die Opgestane verkondig. Na hierdie getuies is dus verwys as getuies vir die Pauliniese evangelie en nie vir die feit van die opstanding nie. Wat vir 'n feit kan dit wees, vra Bultmann, as die werklikheid daarvan saamhang met die opstanding van die dooies (Bultmann 1948a:48)? Die berig oor die leë graf is 'n legende waarvan Paulus nog niks geweet het nie. Volgens die tradisie wat hy in 1 Korintiërs 15:5-8 aangehaal het oor die verskynings van Jesus, is sy opstanding tegelyk as sy verhoging verstaan. Dit is eers later dat daaraan die betekenis geheg is van 'n tydelike terugkeer na die aarde toe, waaruit toe die berig oor die hemelvaart ontstaan het (Luk 24:50-53; Hand 1:3-11; Bultmann 1968a:48).

Vir sy oortuiging dat die berig oor die leë graf nie gebaseer is op 'n historiese gebeurtenis nie (kyk bv ook Broer 1986:53) en daarom gesien moet word as 'n legende (apologetische Legende; Lüdemann 1994:138) wat eers betreklik laat, dit wil sê ná die tradisies oor die verskynings ontstaan het, het Bultmann steun uit verskeie oorde gekry. Hierdie oortuiging is in die jongste tyd ook deur Lüdemann uitgespreek met sy kontensie dat die ontstaan van die graftradisie 'n antwoord was op die Jode se vraag na die verdwyning van die liggaam van Jesus, dat die tradisies oor die leë graf en die verskynings oorspronklik niks met mekaar te doen gehad het nie, maar eers later met mekaar in verband gebring is en dat die eerste 'verskyning' derhalwe nie by die graf plaasgevind het nie (Lüdemann 1994:190).

Soos verwag kon word, het Bultmann se standpunt dat die opstanding slegs gesien moet word as die uitdrukking van die betekenis van die kruis eweneens nie sonder kritiek gebly nie. So het byvoorbeeld Kessler (1987:177) geoordeel dat hierdie standpunt dreig om die opgestane en verskynende Christus, wat deur die Nuwe Testament deurgaạns vóór en bó die Paasgeloof georden is, te laat vervlugtig. En na aanleiding van veral Bultmann se opmerkings rakende die tradisie oor die leë graf het Robinson (1984:152) gewaarsku dat as 'n mens niks van hierdie tradisie as histories aanvaar nie, jy gevaar loop om dit af te skryf as bloot die objektivering van die mite van die kruis as Christus se oorwinning oor die dood. Die implikasie hiervan sou dan wees dat wat ook al 'gebeur' het, innerlik en geestelik gebeur het, nie met die liggaam van Jesus nie maar met die geloof van die apostels (Robinson 1984:152). Min of meer in lyn hiermee oordeel Painter dat Bultmann nie oortuigend is in sy kontensie dat daar nie 'n fisiese opstanding plaasgevind het nie, aangesien Paulus en ander klaarblyklik geglo het in 'n fisiese opstanding van Jesus (Painter 1987:155). Hierdie kritiek van Painter gaan egter nie op nie. Bultmann het nie ontken dat die eerste gelowiges en ook Paulus dit so 
verstaan het dat Jesus liggaamlik opgestaan het nie. Dit is klaarblyklik wat hulle wou tuisbring by dié aan wie hulle die opstanding verkondig het. Die vraag is net of hulle nie in hierdie geval tipies mitologies oor die opstanding gedink het nie, dit wî sê histories-objektiverend gedink het oor iets wat nie as 'n historiese gebeurtenis geklassifisoer kan word nie. En wat Kessler en Robinson se bedenkinge betref, hang dit uiteindelik maar weer af van wat 'n mens onder die voor- en bowe-ordening van die opgestane en verskynende Christus vóór en bó die Paasgeloof verstaan en hoe jy meen om histories oor die opstanding te praat. Hieronder kom ons op hierdie saak terug.

Wat 'n mens tog laat wonder oor die gedagte dat die opstanding niks meer is as die uitdrukking van die betekenis van die kruis nie, is of 'n mens werklik die opstanding benodig om die betekenis van die kruis aan die lig te bring. Anders gestel, sou byvoorbeeld Paulus die opstanding nodig gehad het om sy besondere interpretasie aan die kruis te geheg het? 'n Mens kan nie anders as om die gevoel te kry dat die opstanding, wat ook al daaronder verstaan moet word, tot 'n blote komplement of miskien selfs tot 'n aanhangsel van die kruis gedegradeer word nie. Dat daar klaarblyklik 'n noue band tussen kruis en opstanding gelê moet word, kan nie ontken word nie. Die vraag is net of die opstanding by Bultmann nie te veel in die kruis opgaan nie.

\section{NIE HISTORIES OF HISTORIES-VERIFIEERBAAR NIE}

\subsection{Nie 'n historiese gebeurtenis nie}

Die vraag is, volgens Bultmann, of Jesus se opstanding nie gewoon 'n mitiese gebeurtenis was nie. 'n Historiese gebeurtenis wat na sy betekenis verstaan sou kon word (das in seiner Bedeutsamkeit zu verstehen wäre), was dit in elk geval nie (Bultmann 1948a: 47). Niemand wat al ernstige oorweging aan die saak geskenk het, kan anders as om op hierdie punt volledig met Bultmann saam te stem nie. Ter ondersteuning van hierdie opvatting kan die volgende woorde van Küng as 'n betreklik verteenwoordigende mening oor die saak beskou word:

$\ldots$ it is not an event which can be verified by historical science with the aid of historical methods. For the raising of Jesus is not a miracle violating the laws of nature, verifiable within the present world, not a supernatural intervention which can be located and dated in space and time. There was nothing to photograph or to record.

(Küng 1976:349). 
Opvallend in lyn hiermee het in die jongste tyd ook die lede van die Jesus Seminar 'n opmerking van een van sy lede onderskryf dat die 'verskynings' van Jesus nie iets was wat 'n mens met 'n videokamera sou kon verfilm nie (kyk Funk 1996:258). Hierby was daar ook 'n sterk konsensus by die Seminar dat Jesus se opstanding nie berus het op wat met sy liggaam gebeur het nie en dat dit nie die herlewing van 'n dooie liggaam behels het nie (Funk 1996:259). Die slotsom waartoe die Seminar oor die saak gekom het, stem bykans volledig ooreen met die volgende uitspraak van Lüdemann (1994: 198): ‘... konkret gesprochen, war das Grab gar nicht leer, sondern voll, wenn es überhaupt ein Einzelgrab gegeben hat, und der Leichnam Jesu ist jedenfalls nicht entwichen, sondern verwest'. Dit is dan ook op grond van hierdie oortuiging en in aansluiting hierby dat Lüdemann (1995:130) uiteindelik verklaar: 'A consistent modern view must say farewell to the resurrection of Jesus as a historical event'.

Dit is algemene kennis dat, met die uitsondering van die Petrusevangelie, daar nêrens in die Nuwe Testament of in die nie-kanonieke vroeg-Christelike literatuur ' $n$ beskrywing van die opstanding gegee word nie. Al wat ons tot ons beskikking het, is die berigte oor die verskynings van die na-Pase Jesus aan sy eertydse volgelinge en ook aan Paulus. Hierby is hierdie berigte van verskillende en uiteenlopende aard en pogings om hulle met mekaar in ooreenstemming te bring, was tot dusver nie geslaagd nie. Die probleme wat ondervind is om hulle in ooreenstemming met mekaar te bring, laat ook vermoed dat hulle eers laat ontstaan het en daarom waarskynlik in baie opsigte tendensieus is. Wat die aard van hierdie verskynings was, is natuurlik 'n kwessie waaroor daar uiteenlopende menings bestaan en reeds baie ink gevloei het. Hieroor later meer.

\subsection{As mitiese gebeurtenis ongeloofwaardig; nie as objektiewe feit vasstelbaar}

Die opstanding kan verder volgens Bultmann om twee redes nie beskou word as 'n verifiërende mirakel op grond waarvan 'n mens met sekerheid in Christus sal kan glo nie. In die eerste plek is dit as mitiese gebeurtenis - die terugkeer van 'n gestorwene in/na die lewe van hierdie wêreld - ongeloofwaardig. In die tweede plek kon dit ten spyte van al die baie getuies nie as objektiewe feit vasgestel word op grond waarvan daar sonder bedenking geglo kon word en die geloof 'n sekere waarborg kon hê nie (Bultmann 1948a:49). Schmithals het daarop gewys dat so min as wat Bultmann Jesus se opstanding verstaan het as die terugkeer van 'n gestorwene na die lewe in hierdie wêreld toe, so min het hy dit verstaan as 'n ontrukking in die Jenseits. Hy het dit eerder verstaan as die verhoging van die gekruisigde tot heerskappy (Schmithals 1967:149). Die EthFUT het op sy beurt in hierdie verband geoordeel dat hoewel Bultmann dit heeltemal reg het dat die opstanding nie histories bewys kan word nie, dit te 
betwyfel is of sy werklikheidsbegrip nog ruimte laat vir sy uitspraak dat die geloof sy grond het in wat vóor en buite die geloof in die opstanding van Jesus gebeur het (EthFUT 1952:36-37). Om te sê dat die geloof sy grond het in wat vó́r en buite die geloof in die opstanding van Christus gebeur het, beteken egter nog glad nie dat daarmee beslis is ten gunste van 'n aanname dat sy opstanding 'n historiese gebeurtenis was nie. Soos hieronder sal blyk, ontken Bultmann nie dat Christus self vir die Paasgeloof van die eerste getuies verantwoordelik was nie, maar daarmee is nog nie gesê dat sy opstanding 'n gebeurtenis was wat voldoen het aan die erkende kriteria om 'n gebeurtenis as histories te klassifiseer nie. 'n Mens kan eenvoudig nie anders as om Bultmann volledig gelyk te gee dat Jesus se opstanding in geen opsig as 'n gebeurtenis binne die aan ons bekende tyd en ruimte beskou kan word nie.

\section{4. 'N ESKATOLOGIESE GEBEURTENIS}

In stede van 'n objektiewe en histories-verifieerbare feit te wees op grond waarvan met sekerheid in die heilsgebeure of in Christus geglo kan word, is sy opstanding veel eerder self voorwerp van geloof en dus nie grond vir geloof nie (Bultmann 1948a:49; 1988:122). En 'n mens kan nie een geloof (dié in die heilsbetekenis van die kruis) deur 'n ander geloof (dié in die opstanding) seker stel nie. Dit is voorwerp van geloof omdat dit baie meer inhou as die terugkeer van 'n dooie na hierdie lewe toe, omdat dit 'n eskatologiese gebeurtenis is. En juis om hierdie rede kan dit nie 'n bekragtigende mirakel wees nie. 'n Mirakel, of dit nou geloofwaardig is of nie, betuig nie die eskatologiese feit van die vernietiging van die doodsmag as sodanig nie; iets wat buitendien nie ongehoords in die sfeer van die mitiese denke is nie. Wat duidelik is, is dat die opstanding van Jesus vir die Nuwe Testament deurgaans die eskatologiese feit is waardeur $\mathrm{Hy}$ die dood tot niet gemaak het en die lewe en onverganklikheid aan die lig gebring het (2 Tim 1:10; Bultmann 1948a:49). Dat Bultmann in hierdie verband van 'n eskatologiese gebeurtenis praat, moet natuurlik gesien word teen die agtergrond van die onderskeid wat hy maak tussen geskiedenis en eskatologie. Hy verstaan eskatologie nie alleen as die einde van die geskiedenis nie, maar ook as die nuwe situasie wat deur die Christusgebeure paradoksaal in die geskiedenis ingetree het deurdat dit vir die gelowige reeds ten volle gerealiseer het, terwyl die geskiedenis steeds voortgaan. Volgens hom het God in Jesus Christus as die eskatologiese gebeurtenis 'n einde aan hierdie wêreld gemaak deur die mens (gelowige) self nuut te maak (Bultmann 1948a:42). Dit hou vir die gelowige die paradokse eksistensiële werklikheid in dat hy/sy 'als gleichsam Entweltlichtes existiert, und daß er zugleich innerhalb seiner Geschichtlichkeit bleibt' (Bultmann 1964:181). Dit beteken egter in feite dat die geskiedenis van die gelowige anderkant die wêreldgeskiedenis lê en dat sy/haar geskiedenis nie langer meer as 'n funksie van die wêreldgeskiedenis verstaan kan word nie (Bultmann 1960a:106). 
Dit is in die lig hiervan dat van die opstanding nie as 'n historiese gebeurtenis gepraat kan word nie, maar alleen as 'n eskatologiese gebeurtenis, as ' $n$ gebeurtenis wat nie binne die dimensie van die geskiedenis plaasgevind het nie.

Dat die opstanding as 'n eskatologiese gebeurtenis verstaan moet word, is-ook deur verskeie ander onderskryf, soos byvoorbeeld deur Wilckens wat ten opsigte van die uitspraak 'Christus is opgewek' (1 Kor 15:20) die volgende stel: 'Denn das Faktum, auf das Paulus sich bezieht, ist ja nicht das eines wunderbar aus dem Tode wieder in sein irdisches Leben Zurückgebrachtwerdens' (Wilckens 1988:185; so oa ook nog Künneth 1982:90). Dit beteken volgens Wilckens dat Paulus Jesus ervaar het as die deur God se eindtydlike daad opgewekte in ooreenstemming met die tradisioneel Joodse verwagting van die eskatologiese opstanding van die dooies (Wilckens 1988:185). As verdere ondersteunende stemme kan genoem word dié van Fuller (1980:170) wat praat van die transformasie van Jesus se hele wese 'into a new mode of eschatological existence' en Kessler (1987:137) wat stel dat Jesus se opstanding nie 'n restourasie was van sy vroeëre lewe, 'n terugkeer na sy aards-tydelike bestaanswyse nie, maar 'n oorgang na die vir ons verborge eskatologiese bestaansvorm by God. Nogtans oordeel Kessler (1987:177) dat dit as die beslissende tekortkoming by Bultmann beskou kan word dat hy uit vrees vir die objektivering van God se eskatologiese handeling en vir 'n valse sekerstelling van die geloof dit vermy het om die teologiese vraag te vra na die besondere karakter van die opstanding en die verskynings van Jesus wat as werklikheid aan die histories vasstelbare Paasgeloof ten grondslag lê. Wat Kessler daarmee bedoel dat Bultmann nie die teologiese vraag na die besondere karakter van die opstanding vra nie, is vir my duister. Bultmann is immers een van die weiniges wat daarvan beskuldig kan word dat hy steeds nie teologiese vrae bly vra het nie.

Op hierdie eskatologiese verklaring van die opstanding het Funk egter skerp kritiek gelewer. Hy beskou die poging om Jesus se opstanding te verklaar as 'n eskatologiese gebeurtenis wat ruimte en tyd transendeer as 'n 'ploy' om dit van wetenskaplike en historiese ondersoek uit te sluit en dit sodoende daarvan te vrywaar (Funk 1996:258). Voor hom het ook ander hulle sterk uitgespreek ten gunste van nie net die legitimiteit nie, maar ook die noodwendigheid van die historiese terugvra na Jesus se opstanding (so bv Pesch 1988:240). 'n Mens moet Funk natuurlik gelyk gee dat die saak oënskynlik maklik as geslote beskou kan word as daar so 'n 'teologiese' verklaring van die opstanding gegee word. Of dit inderdaad die geval is, sal ons nog moet oorweeg. 


\section{5. 'N GELOOFSWERKLIKHEID}

\subsection{Slegs geloofswerklikheid, net soos die betekenis van die kruis}

Hoewel Bultmann, soos reeds hierbo gemeld, die opstanding sien as uitdrukking van die betekenis van die kruis, beskou hy dit nie as 'n mitiese gebeurtenis wat die betekenis van die kruis geloofwaardig kan maak nie. Dit word immers net so geglo as wat die betekenis van die kruis geglo word. Ja, die opstandingsgeloof is niks anders as geloof in die kruis as heilsgebeurtenis, in die kruis as kruis van Christus nie. Sou ons vra hoe 'n mens daartoe kom om in die kruis as heilgebeurtenis te glo, is daar net één antwoord moontlik: 'n Mens glo in die kruis omdat dit as heilsgebeurtenis verkondig word, omdat dit saam met die opstanding verkondig word. Dit is ook die geloof waarmee die ergernis van die kruis oorkom word (Bultmann 1948a:50). Wat vir die kruis geld, geld vanselfsprekend ook vir die opstanding: 'n mens glo in die opstanding omdat dit verkondig word, nie omdat dit as historiese bewysgrond vir die geloof dien nie.

\subsection{Niks anders as ontstaan van geloof in die Opgestane nie}

Die Paasgebeurtenis, vir sover dit as historiese gebeurtenis naas die kruis genoem kan word, is dus niks anders as die ontstaan van die geloof in die Opgestane nie, die geloof waarin die verkondiging sy oorsprong gehad het (Bultmann 1948a:50). Volgens die Johannes-evangelie is Jesus se opstanding, Pinkster en Jesus se paroesie een gebeurtenis - nie 'n kosmiese of mitiese gebeurtenis nie maar die beslissende gebeurtenis van die terugkeer van die van-die-aarde-verwyderde Jesus in die ervaring van geloof.

\subsection{Slegs Paasgeloof van eerste dissipels as historiese gebeurtenis te verstaan}

Die Paasgebeurtenis as die opstanding van Christus is daarom nie ' $n$ historiese gebeurtenis nie; net die Paasgeloof van die eerste dissipels is as historiese gebeurtenis te verstaan ('faßbar'; Bultmann 1948a:51; 1960b:204; kyk ook Kessler 1987:141). Volgens die beslissende uitsprake van die Nuwe Testament is die Paasgeloof gewoonweg gegrond op die verkondiging van die Paasbelewenisse van die eerste getuies (Bultmann 1988:122). Die dat van hierdie belewenisse, vir die geloof die selfbekendmaking van die Opgestane, is die beslissende van die Paasverkondiging (Bultmann 1988:122). Die volgelinge van Jesus moes as gevolg van die kruis tot 'n nuwe geloofsbeslissing kom. Hulle moes die ergernis van die kruis oorkom en dit het hulle gedoen deur die Paasgeloof. Hoe elkeen van hulle tot hierdie beslissing gekom het en hoe die Paasgeloof by elkeen ontstaan het, is in die oorlewering deur legendes verduister en is saaklik van geen betekenis nie (Bultmann 1968a:47). Die historikus kan die ontstaan daarvan tot op sekere hoogte probeer verklaar deur dit toe te skryf aan visioene wat die volgelinge 
van Jesus gehad het op grond van die vroeëre verbondenheid wat daar tussen hulle en Jesus bestaan het. Die Christelike Paasgeloof is egter nie in die historiese vraag geïnteresseer nie. Vir die Christelike Paasgeloof is die historiese gebeurtenis van die ontstaan van die Paasgeloof, soos vir die eerste volgelinge van Jesus, die selfbekendmaking van die Opgestane, die daad van God waarin die heilsgebeure van die kruis tot voleinding kom (Bultmann 1948a:51; 1988:121).

Die EthFUT het ter ondersteuning hiervan gewaarsku dat indien 'n mens die gedagte prysgee dat die opstandingsgebeure net deur die opstandingsgeloof bevestig kan word, daar 'n dubbele vervalsing dreig. Indien die opstanding beskou sou word as 'n feit op die oortuigingskrag waarvan die geloof kan bou, sal 'n mens die opstanding nie meer as daad van God verstaan nie maar slegs as 'n wonderbaarlike natuurgebeure. Tegelyk word hiermee die geloof verander tot 'n houding wat waarborge soek buite die woord om waardeur 'n mens tot geloofsbeslissing gebring word. Nogtans het die fakulteit in hierdie verband ook 'n bedenking uitgespreek, naamlik dat terwyl Bultmann daarin reg is dat die opstandingsgebeure en die opstandingsgeloof nie van mekaar geskei kan word nie, hy nie meer in staat is om die twee te onderskei nie. Dit bring hom onder die verdenking dat hy die opstanding ten volle in die opstandingsgeloof laat opgaan (EthFUT 1952:36).

Hierbo is reeds daarop gewys dat daar, uitgesonderd die Petrusevangelie, nêrens in die vroeg-Christelike literatuur ' $n$ beskrywing van die opstanding self gegee word nie, maar slegs dat mense berig het dat Jesus aan hulle verskyn het. Daar is ook op gewys dat terwyl hierdie feit algemeen erken word, daar uiteenlopende menings is oor hoe die 'verskynings' geïnterpreteer moet word. Die vraag waarom dit in hoofsaak hier gaan, is: was dit objektiewe gebeurtenisse waarin die Opgestane die handelende was en die waarnemers of getuies die ontvangers of was dit subjektiewe ervarings of geloofsprojeksies van die kant van Jesus se volgelinge, en selfs sy vervolger Paulus? Soos ons gesien het, is Bultmann se standpunt hieroor enersyds dat historiese terugvra onmoontlik is, aangesien die ervarings wat die getuies sou gehad het, deur legendes verduister is en andersyds dat dit geen sin het om terug te vra nie, aangesien dit saaklik van geen betekenis vir die geloof is nie (kyk weer Bultmann 1968a:47). Wie bekend is met Bultmann se beskouing oor die bruikbaarheid van die resultate van historiese ondersoek sal weet dat hy hom in hierdie verband grootliks aangesluit het by veral Kähler, Hermann en Troeltsch, en dat hy hierin gevolg is deur mense soos Barth, Tillich, Ebeling, Fuchs en Bornkamm (vgl Carnley 1987:103-105, 132-133). Afgesien van sy prinsipiële beswaar teen die bou van geloof op die resultate van historiese ondersoek, het hy geen sodanige resultaat as volledig betroubaar, finaal en van nie-relatiewe aard beskou nie. Hoewel hierdie benadering by baie byval gevind het, het dit nie sonder kritiek gebly nie. ' $n$ Voorbeeld van sodanige kritiek vind ons by Carnley (1987:133) wanneer hy sê dat hierdie standpunt daarop neerkom dat geloof 'mistress in her own household' gemaak is en dat alle historiografiese oordele 'logically erroneous' is. Dit berus ook 
vir hom op 'n logiese illusie deurdat daarvan uitgegaan word dat 'n 'purely logical possibility of error' 'n 'actual possibility of error' inhou (kyk Carnley 1987:134). So oordeel ook Lüdemann (1994:21-26) dat die beswaar dat daar nie histories teruggevra kan word nie, onder andere omdat daar nie ' $n$ beskrywing van die opstanding gegee is nie, dat die verwarrende tradisies oor die verskynings nie ontwar kan word nie en dat oor die opstanding nie los van die geloofservarings en getuienis van die volgelinge van Jesus gepraat kan word nie, geen verskoning is om 'n wetenskaplik-historiese ondersoek na die opstanding van Jesus te weier nie. Hoewel daarmee volledig saamgestem moet word dat kritiese en deurtastende historiese ondersoek hoegenaamd nie op grond van sogenaamde teologiese of geloofsgronde nagelaat of geweier mag word nie, het ons steeds te kampe met die probleem dat ons niks meer tot ons beskikking het as die geloofsweergawes van getuies wat nie as onbetrokke waarnemers geklassifiseer kan word nie. Dit is buite diskussie dat, behalwe in die geval van Paulus, ons te doen het met die weergawes van belewenisse van eertydse volgelinge van Jesus ten opsigte waarvan historiese verifikasie minstens geweldig problematies indien nie onmoontlik is nie. En selfs al aanvaar ons dat daar mense soos Petrus en Paulus was wat in 'n sekere sin werklik iets beleef het, bly die moeilike vraag nog wat dan die aard daarvan was. Soos verskeie ander, oordeel ook Kessler (1987:233-235) dat ons wel nog die dat en die wat histories kan postuleer maar nie die hoe nie.

Volgens Lüdemann het die eerste visioen van Petrus eintlik maar al die ander tot gevolg gehad: "Die Erstvision vor Kephas wirkte förmlich "anstekkend", ihr folgten unmittelbar weitere' (Lüdemann 1994:192). As voorbeeld hiervan kan genoem word die massapsigose in die geval van die 'meer as vyf honderd broers' (1 Kor 15:6; Lüdemann 1994:123). Indien Lüdemann dit reg het, kom dit daarop neer dat 'n historiese terugvra na die hoe van die verskyningsbelewenisse hoogstens op Petrus se ervaring sal moet konsentreer, hoewel die belewenis van Paulus waarskynlik tog ' $n$ besondere plek inneem, synde dié van 'n persoon wat nie 'n volgeling van Jesus was nie, maar ' $n$ vervolger van die kerk. Wat die verskyningsbelewenisse van veral Petrus en Paulus betref, druk Lüdemann hom verstaanbaarder uit in die verkorte weergawe van sy hierbo genoemde oorspronklike publikasie, te wete What really happened to Jesus: A historical approach to the resurrection (1994). Hiervolgens kan beide die visoene van Petrus en Paulus as oorspronklike visioene getipeer word omdat hulle sonder eksterne katalisators plaasgevind het, bedoelende, soos hierbo gestel, dat hulle nie deur ander visioenarisse se visioene 'aangesteek' is nie. In albei gevalle is dit veroorsaak deur ' $n$ bepaalde psigiese wanbalans. In Petrus se geval, is dit veroorsaak deur 'n skuldgevoel: 'Peter received the first vision, which is to be interpreted psychologically as failed mourning and the overcoming of a severe guilt complex' (Lüdemann 1995:129). In Paulus se geval, daarenteen, is dit veroorsaak deur 'n Christuskompleks van 'n 'vyand' van Jesus: 'Here Paul's biography gives strong indications that his vision of Christ is to be explained psychologically as an overcoming of a smouldering "Christ complex" 
which led to severe inner (unconscious) conflicts in him and finally released itself in this vision' (Lüdemann 1995:130). So gesien, is dit dus ál wat histories vas te stel is in verband met die verskyningsbelewenisse van die eerste getuies. Dit impliseer volgens Lüdemann dat daar afstand gedoen moet word van die standpunt dat God die outeur van hierdie visioene was, aangesien hulle psigologiese prosesse was wat volledig sonder Goddelike ingrype plaasgevind het. Dit impliseer verder dat ' $\mathrm{n}$ aanname dat Jesus opgestaan het 'as a presupposition to explain these phenomena' (Lüdemann 1995:130) volkome onnodig is. Lüdemann het hiermee op ' $n$ terrein beweeg wat in sigself baie onverklaarbare dinge huisves en uitvoerige diskussie verg wat binne hierdie bestek nie moontlik is nie. Die psigologiese verklarings wat hy gee, is nie sommer te negeer nie. Die vraag is egter net wat daar werklik by psigiese prossesse in die gedrang is. Om hierop ' $n$ antwoord te gee, val ongelukkig buite my kompetensie.

Funk gaan nog verder as Lüdemann deur te stel dat die aansprake op apostoliese voorregte en outoriteit, wat op die verskyningsberigte gebaseer is, verwerp moet word. Volgens hom funksioneer die berigte oor Jesus se verskynings aan sekere van sy volgelinge in die evangelies en briewe as 'commissioning stories' waardeur sekere leiers vir hulleself die alleen-outoriteit en posisie opgeëis het om die evangelie te verkondig, met die uitsluiting van ander. Om hierdie rede het die verskyningsvertellings fundamenteel eie belang gedien. Hulle is ' $n$ 'belated and oblique recognition of the vision Jesus had of God's dominion over creation' en hulle het niks bygedra tot wat teologies en eties as die essensiële inhoud van die Christelike geloof gesien kan word nie (Funk 1996:313). Dit is om hierdie rede dat Funk so 'n uitgesproke standpunt oor die geloof van die eerste getuies inneem: 'We can no longer rest our faith on the faith of Peter or the faith of Paul' (Funk 1996:304). So 'n geloof is volgens hom 'n tweedehandse geloof. Daarom moet daar deurgedring word na Jesus van Nasaret toe vir ware geloof, vir fundamentele geloof. Hierdie beskouing van Funk spruit daaruit dat hy eintlik wil dat ons moet afstand doen van die tradisionele Paasgeloof, aangesien die berigte oor die verskynings niks meer was nie as 'a diluted and not altogether satisfactory glimpse of what Jesus glimpsed' (Funk 1996:313). Dit hou in dat die aanspraak dat Jesus opgestaan het, ' $n$ wyse is van te bely dat Hy openbaar het wat die wêreld werklik is, dat Hy 'n kykie in die ewigheid in gekry het. Om te weet wat Hy gesien het, moet ons gaan kyk na sy gelykenisse en aforismes (Funk 1996:313).

Dit is belangrik om daarop te let dat hoewel Bultmann die historiese terugvra na die Paasbelewenisse van die eerste getuies as onmoontlik en van geen betekenis beskou, hy dit klaarblyklik nie soos Lüdemann bloot aan psigiese prosesse toegeskryf het of soos Funk as later gefabriseerde roepingsvertellings gesien het nie. Hy het dit ook nie soos Marxsen slegs as die geboorte van geloof by die Jesusvolgelinge ('n 'non-event' volgens Carnley 1987:154-162) beskou, en die woorde 'Jesus het opgestaan' as maar net één van die wyses om aan hierdie 'tot geloof kom' uitdrukking te gee nie (kyk Marxsen 1975:128). Hierdie feit blyk duidelik daaruit dat hy van hierdie geleenthede 
praat as die selfbekendmaking van die Opgestane en as 'n daad van God (kyk weer Bultmann 1948a:51; 1988:121). Dit word ook bevestig deur 'n mededeling van Küng (1976:351) na aanleiding van 'n gesprek wat hy met Bultmann gehad het. Volgens Küng het Bultmann op die vraag of die opstanding van Jesus liggaamlik was, 'nee' geantwoord indien liggaan verstaan sou word as fistologies identiese liggaam, maar ' $\mathrm{ja}$ ', indien dit in terme van die Nuwe-Testamentiese $\sigma \hat{\omega} \mu \alpha$ verstaan sou word as identies persoonlike realiteit, die eie self met sy hele geskiedenis. Met ander woorde nie die kontinuering van die liggaam nie, maar die identiteit van die persoon. Om agter te kom hoe Bultmann hom hierdie 'objektiewe' werklikheid van die opgestane Christus voorgestel het, moet 'n mens kyk na wat hy oor die ontmoeting met die Opgestane sê, soos ons hieronder sal doen.

\subsection{Paasgeloof van eerste dissipels egter nie geloofsgrond nie}

Die Paasgeloof van die eerste dissipels is egter ook nie ' $n$ feit op grond waarvan 'n mens glo, sodat 'n mens se eie Paasgeloof nie meer vir jou 'n waagstuk sal wees nie (Bultmann 1948a:51). Jy moet die waagstuk van die geloof net so voltrek soos hulle dit voltrek het. 'n Mens is wel van hulle 'ervaring' afhanklik, want hierdie ervaring, wat self deel is van die Christusgebeure, is die gebeurtenis waarin Christus Homself as die Verhoogde bewys (Bultmann 1988:122). Wat van 'n mens gevra word, is of jy die geloofsdaad van die eerste getuies op so 'n wyse wil na-voltrek (nachvollziehen) dat jy hierdie gebeurtenis, naamlik die ontstaan van die Paasgeloof as selfbekendmaking van die Opgestane, as beslissende daad van God erken (Bultmann 1988:121). Die rede waarom die Paasgeloof van die eerste dissipels nie as feit kan dien op grond waarvan 'n mens kan glo nie, berus enersyds daarop dat 'n mens nie jou geloof op die geloof van 'n ander kan bou nie (kyk ook Schmithals 1967:141). Andersyds maak dit self deel uit van die eskatologiese gebeure wat die objek van geloof is. Met ander woorde die verkondigingswoord wat in die Paasgebeure ontspring het, is self deel van die eskatologiese heilsgebeure. 'Im erklingen des Wortes werden Kreuz und Auferstehung Gegenwart, ereignet sich das eschatologische Jetzt'. Dit is hierdie woord wat by die kruis 'bykom' en dit as heilsgebeure verstaanbaar maak deurdat dit geloof van 'n mens vra en aan 'n mens die vraag stel of jy jou as saamgekruisigde en daarmee ook as saamopgestane wil verstaan (Bultmann 1948a:51). Dit is volgens Bultmann 'n dwaling om te wil terugvra na die historiese oorsprong van die verkondiging as sou daarmee die legitimiteit van die verkondiging bewys kon word. Dit sou beteken dat 'n mens die geloof in God se woord deur historiese ondersoek wil bewys. Die woord van die verkondiging ontmoet ons as die woord van God, die woord ten opsigte waarvan 'n mens nie legitimiteitsvrae mag vra nie, maar wat van óns vra of ons dit wil glo of nie. Dit stel die vraag só dat terwyl dit ons gebied om in die dood en opstanding van Christus as eskatologiese gebeure te glo, dit vir ons die moontlikheid tot selfverstaan open (Bultmann 1948a:50). 
Dit is uit die onmiddellik voorgaande duidelik dat Bultmann twee van sy prinsipiële standpunte konsekwent bly handhaaf. In die eerste plek handhaaf hy ten opsigte van die vraag na die historiese fundering van geloof die standpunt dat die resultate van historiese ondersoek nie, selfs nie in die geval van die geloof van die eerste getuies, latere geloof kan verifieer of valsifiseer of legitimeer nie. In die tweede plek handhaaf hy sy oortuiging dat geloof 'n waagstuk is waarin 'n mens daarvan afsien om op die Verfügbare te bou en jou volledig verlaat op die Unverfuigbare, op God en sy woord. Dit kom daarop neer dat as 'n mens die geloof van die eerste getuies wil seker stel as grond vir geloof wat daarop gevolg het, jy geloof een van sy mees kenmerkende karaktertrekke sal ontneem, naamlik dat geloof 'n waagstuk is en juis nie op sien gebou is nie.

Dit is op hierdie punt nodig om terug te kom op Funk se oortuiging dat 'n mens nie langer meer jou geloof op die geloof van die eerste getuies kan bou nie. Soos ons gesien het, is dit Funk se beswaar dat die eerste getuies 'n verwaterde en onbevredigende weergawe gegee het van wat Jesus gesien het en dat daar daarom agter hulle getuienisse na Jesus toe teruggevra moet word. Hierbo is reeds meermale daarop gewys dat die getuienis van die eerste getuies tendensieus was en dat elkeen gerapporteer het soos hy 'gesien' het. Dit is dus algemene kennis dat die geloof van die eerste getuies gespruit het uit hulle persepsie van die Christusgebeure, ingesluit die 'opstanding' van Jesus. Maar wat van die opstanding as nie-historiese 'gebeurtenis' geld, geld eweneens van die kruisiging as historiese (historische) gebeurtenis. Wat Paulus van die kruisiging van Jesus gemaak het, naamlik dat hy daarvan die kruis van Christus gemaak het met die (geschichtliche) betekenis daaraan geheg, is klaarblyklik nie hoe Jesus oor sy dood gedink het nie. Tradisioneel het die Christendom sterk gebou op die gedagte van versoening deur die dood/bloed van Christus waarin kruis en opstanding die sentrale rol gespeel het, veral soos Paulus dit verstaan het. Ook hiervan wil Funk dat afstand gedoen moet word, aangesien Jesus nie so oor God se handelinge met die mense gedink het nie (Funk 1996:312). Dit bring ons maar weer by die ou vraag van Jesus en Paulus (en Johannes en die ander) waarop nie binne hierdie bestek ingegaan kan word nie.

Intussen kan ons egter ook nie Funk se argumente maklik van die tafel afvee nie. Dit is eenvoudig ' $n$ feit dat ons ons verlaat op die getuienis en geloof van getuies wat enersyds nie op absolute betroubaarheid aanspraak kan maak nie en andersyds hulle eie persepsies oor die Christusgebeure oorgelewer het. Uiteindelik moet elkeen besluit of hy/sy hierdie getuienis as haalbaar of sinvol en singewend wil aanvaar of nie, hom/haar kan vereenselwig met hierdie getuies se Existenzverständnis of nie, om so tot 'n ooreenstemmende Selbstverständnis te kom of nie. Feit bly dat ons oor Jesus se 'opstanding' en hoe dit verstaan is, niks meer en niks anders tot ons beskikking het as die getuienisse van die eerste getuies nie. Om histories agter hierdie getuienis terug te vra, is eenvoudig nie moontlik nie. 


\section{CHRISTUS STAAN IN DIE VERKONDIGING OP}

\subsection{Die Opgestane ontmoet net in die verkondiging}

Christus die gekruisigde en opgestane ontmoet ons in die woord van die verkondiging, nêrens anders nie (Bultmann 1948a:50; 1948b:148; vgl ook Bultmann 1952:206; 1958b:180). 'Im gepredigten Wort und nur in ihm begegnet der Auferstandene' (Bultmann 1948a:51). Juis die geloof in hierdie woord is in werklikheid die Paasgeloof (Bultmann 1948a:50). Soos reeds hierbo gestel, is dit volgens Bultmann 'n dwaling om te wil terugvra na die historiese oorspronge van die verkondiging, asof die verkondiging die reg van sy bestaan kan bewys. Dit sou beteken dat ons die geloof in die woord van God deur historiese ondersoek wil begrond. Die woord van die verkondiging kom na ons toe as God se woord ten opsigte waarvan ons nie 'n legitimeringsvraag kan vra nie, maar wat net van ons vra of ons dit wil glo of nie. Dit vra ons egter só dat terwyl dit ons gebied (gebietet) om in die dood en opstanding van Christus as eskatologiese gebeure te glo, dit tegelyk vir ons die moontlikheid open om tot selfverstaan te kom (Bultmann 1948a:50). Indien dit so is dat die kerugma Jesus as die Christus, as die eskatologiese gebeure verkondig, en daarop aanspraak maak dat Christus daarin teenwoordig is, dan het die verkondiging in die plek van die historiese Jesus getree, dan verteenwoordig dit vir Jesus (Bultmann 1965:26). En indien dit korrek is om te sê dat die kerk in sy verkondiging die historiese Jesus verteenwoordig (vertritt) en dat die geloof in Christus tegelyk die geloof in die kerk, respektiewelik die geloof in die Gees is, dan kan ' $n$ mens sê dat om in die kerk as die draer van die kerugma te glo, die Paasgeloof is, wat juis uit die geloof bestaan dat Jesus Christus in die kerugma teenwoordig is (Bultmann 1965:27). Sien 'n mens dit so, sê Bultmann, word al die spekulasies oor die synswyse van die Opgestane, al die vertellings oor die leë graf en alle Paaslegendes, watter elemente van historiese feite hulle ook al mag bevat, van geen belang nie (gleichgültig). $\mathrm{Om}$ in die in-die-kerugma-teenwoordige-Christus te glo, is die sin van die Paasgeloof (Bultmann 1965:27). Hiermee word die opstanding van 'n mitieshistoriese gebeure getransponeer na 'n eskatologies-eksistensiale gebeure in die hede (so tereg Kay 1994:104).

Dit is bekend dat dit voor Bultmann se deur gelê is dat sy bogenoemde stelling dat die sin van die Paasgeloof is om in die in-die-kerugma-teenwoordige-Christus te glo, daarop neerkom dat Christus nie anders as in die kenugma opgestaan het nie. Hierop het hy geantwoord: 'Ich akzeptiere diesen Satz. Er ist völlig richtig, vorausgesetzt daß er richtig verstanden wird. Er setzt voraus, daß das Kerygma selbst eschatologisches Geschehen ist; und er besagt, daß Jesus im Kerygma wirklich gegenwärtig ist, daß es sein Wort ist, das den Hörer im Kerygma trifft' (Bultmann 1965:27). 
Robinson, wat ernstige bedenkinge uitgespreek het teen die rol wat Bultmann op hierdie wyse aan die verkondiging toeskryf, het daarna verwys as die 'excessive Lutheran trust in the sermon as the place where the Easter-event happens' (Robinson 1984:151). Funk oordeel weer dat Bultmann se weiering om agter die kerugma terug te vra na Jesus se opstanding, as gevolg waarvan hy Jesus in die kerugma moes laat opstaan, eintlik maar 'n neo-ortodokse poging was om die gevolge van historiese kritiek te ontwyk. 'Neo-orthodoxy was a powerful and subtle form of orthodoxy designed to protect against the negative effects of historical criticism and the modern scientific temper' (Funk 1996:303). Küng (1976:352) het egter tereg daarop gewys dat Bultmann nie hiermee beweer het dat Jesus lewe omdat Hy verkondig word nie, maar dat $\mathrm{Hy}$ verkondig word omdat $\mathrm{Hy}$ lewe. 'n Mens verstaan Bultmann dus verkeerd as jy veronderstel dat hy Christus eers in die kerugma laat opstaan. Wat hy wel hiermee sê, is dat dit alleen in die kerugma is dat Christus homself as die Opgestane teenwoordig stel en as sodanig ontmoet word. Maar dan is dit duidelik ook weer nie 'n ontmoeting wat 'n mens as 'n onbetrokke waarnemer objektief kan waarneem nie. Dit kan alleen eksistensieel ervaar word wanneer 'n mens deur die hoor en die glo van die verkondiging jou saam met Christus laat kruisig om saam met Hom op te staan. Buite hierdie eksistensiële ervaring om het Christus nie vir jou opgestaan nie, sodat ál wat jy van sy opstanding kan sê, dit is wat jy eksistensieel daarvan ervaar.

\subsection{Geloof in die verkondiging is egte Paasgeloof}

Die verstanende geloof in die woord van die verkondiging is die egte paasgeloof. Die waarheid van die opstanding van Christus kan nie vóór die geloof wat die Opgestane as Here erken, ingesien word nie. Die feit van die opstanding kan - ten spyte van 1 Korintiërs 15:3-8 - nie as 'n objektief vasstelbare feit op grond waarvan 'n mens kan glo, bewys of duidelik gemak word nie. Dit kan alleen geglo word en alleen in soverre dit, respektiewelik die Opgestane, in die verkondigde woord teenwoordig is. 'Der Glaube an die Auferstehung Christi und der Glaube, daB im verkündigten Wort Christus selbst, ja Gott selbst, spricht (2. Kr 5,20), ist identisch' (Bultmann 1968a:305; kyk ook .Bultmann 1958a:208). Hoor die hoorder hierdie woord as die tot hom/haar gesproke, hom/haar die dood en daardeur die lewe toesprekende woord, dan glo hy/sy in die Opgestane.

Wat hieruit nog eens duidelik word, is dat die verkondiging gehoor en geglo moet word om die Opgestane in die verkondiging as Opgestane te kan ontmoet. Buite die geloof wat die verkondigde as Opgestane ervaar, is Hy eenvoudig nie vir die gelowige die Opgestane nie. En om weer te herhaal, geloof in die Opgestane realiseer nie anders as dat die gelowige deur die geloof die saam-met-Hom-gekruisigde en saam-met-Hom- 
opgewekte is nie. Om dus van die opstanding van Christus in algemene of objektiewe terme te praat sonder om jouself te verstaan as daardeur in beslag geneem en tot ' $n$ nuwe mens gemaak te wees, is mitiese spreekwyse wat as sodanig geen eksistensiële betekenis vir die geloof het nie.

\section{SLOTOPMERKINGS}

Dit is uit die voorgaande meer as duidelik dat Bultmann aan die een kant elke gedagte verwerp dat Jesus se opstanding die herlewing van sy dooie liggaam en daarom 'n historiese gebeurtenis was. Aan die ander kant is dit net so duidelik dat hy die opstanding ook nie gesien het as bloot die ontstaan van die Paasgeloof by Jesus se volgelinge nie. Hy praat van Jesus se opstanding enersyds as sy verhoging en andersyds as sy terugkeer in die ervaring van die geloof. Hoewel hy die laasgenoemde stelling met name uit die Johannesevangelie ontleen, vereenselwig hy hom klaarblyklik met Johannes se verstaan van sake. Wat egter belangrik is van Bultmann se standpunt is dat hy die verkondiging sien as die enigste teologies legitieme moontlikheid van spreke oor die opstanding van Jesus. Maar net so belangrik is dit dat hy die hoor en die glo van die verkondiging van die Opgestane sien as die enigste ware Paasgeloof. Vrae buite die verkondiging en die geloof in die verkondiging om is legitimeringsvrae, wat wel gevra kan word, maar wat niks met geloof te make het nie. As geloof nie meer ' $n$ waagstuk is wat dit met die getuienis van die eerste getuies waag nie, is dit nie meer geloof nie en is daar nie meer sprake van geloof as die eksistensiële ervaring van die sterwe saam met Christus en die lewe saam met Hom nie. Dit lyk of 'n mens met reg namens Bultmann kan sê dat Jesus uiteindelik in die geloof opstaan, dat Hy eers vir jón opstaan wanneer jy werklik in Hom as die Opgestane glo. Buite jou geloof om kan jy Hom dus nie as die Opgestane herken of erken en Hom as die lewende en lewendmakende Here ervaar nie.

Hierdie poging om iets van Bultmann se denke te verstaan en te probeer deurgee aan wie ook al vir ons tyd daarin mag belangstel, word aangebied ter ere van 'n jarelange en gewaardeerde vriend en kollega, Johannes Engelbrecht. Dit word aangebied met die vertroue dat hy dit sal ervaar as ' $n$ huldeblyk wat sy persoon waardig is.

\section{Literatuuraanwysings}

Broer, I 1986. 'Der Herr ist wahrhaft auferstanden' (Luk 24,34): Auferstehung Jesu und historisch-kritische Methode. Erwägungen zur Entstehung des Osterglaubens, in Broer, I (Hrsg), Auferstehung Jesu-Auferstehung der Christen: Deutungen des Osterglaubens, 39-62. Freiburg: Herder. (QD 105.) 
Bultmann, R 1948a. Neues Testament und Mythologie: Das Problem der Entmythologisierung der neutestamentlichen Verkündigung, in Bartsch, H W (Hrsg), Kerygma und Mythos: Ein theologisches Gespräch 1, 15-53. Hamburg: Rein \& Heidrich evangelischer Verlag. (ThF 1.)

- 1948b. Zu J. Schniewinds Thesen das Problem der Entmythologisierung betreffend, in Bartsch, H W (Hrsg), Kerygma und Mythos: Ein theologisches Gespräch 1, 135-153. Hamburg: Rein \& Heidrich evangelischer Verlag. (ThF 1.)

- 1952. Die Rede vom Handeln Gottes, in Bartsch, H W (Hrsg), Kerygma und Mythos: Ein theologisches Gespräch. Diskussionen und Stimmen zum Problem der Entmythologisierung 2, 196-208. Hamburg: Herbert Reich evangelischer Verlag. (ThF 2.).

- 1958. Glauben und Verstehen: Gesammelte Aufsätze, I. Tübingen: Mohr.

[1929] 1958a. Die Bedeutung des geschichtlichen Jesus für die Theologie des Paulus, in Bultmann 1958:188-213.

- [1929] 1958b. Kirche und Lehre m Neuen Testament, in Bultmann 1958:153187.

- 1958c. Zur Frage des Wunders, in Bultmann 1958:214-228.

- 1960. Glauben und Verstehen: Gesammelte Aufsätze, III. Tübingen: Mohr.

- [1957] 1960a. Geschichte und Eschatologie im Neuen Testament, in Bultmann 1960:91-106.

_ [1958] 1960b. Das befremdliche des christlichen Glaubens, in Bultmann 1960:197-212.

- [1957] 1964. Geschichte und Eschatologie. 2. Aufl. Tübingen: Mohr.

- 1965. Das Verhältnis der urchristlichen Christusbotschaft zum historischen Jesus. 4. Aufl. Heidelberg: Carl Winter Universitätsverlag. (SHAW 3.)

1968a. Theologie des Neuen Testaments. 6. Aufl. Tübingen: Mohr.

__ 1968b. Das Evangelium des Johannes. Göttingen: Vandenhoeck. (KEK.)

- [1940] 1988. Die Auferstehungsgeschichte und der christliche Glaube: Rezension über Emmanuel Hirsch, in Hoffmann 1988:118-125.

Carnley, P 1987. The structure of resurrection belief. Oxford: Clarendon.

Ev.theol. Fakultät der Universität Tübingen 1952. Für und wider die Theologie Bultmanns: Denkschrift der Ev.theol. Fakultät der Universität Tübingen, dem württembergischen Landeskirchentag überreicht am 11.3.1952. Tübingen: Mohr. (SGV.)

Fuller, R H 1980. The formation of the resurrection narratives. Revised ed. London: SPCK.

Funk, R W 1996. Honest to Jesus: Jesus for a new millennium. San Francisco: Harper. 
Hoffmann, P (Hrsg) 1988. Zur neutestamentliche Überlieferung von der Auferstehung Jesu. Darmstadt: Wissenschaftliche Buchgesellschaft. (WdF 522.)

Kay, J F 1994. Christus Praesens: A reconsideration of Rudolf Bultmann's Christology. Grand Rapids: Eerdmans.

Kessler, H 1987. Sucht den Lebenden nicht bei den Toten: Die Auferstehung Jesu Christi in biblischer, fundamentaltheologischer und systematischer Sicht. 2. Aufl. Düsseldorf: Patmos.

Küng, H 1976. On being a Christian, tr by E Quinn. Garden City: Doubleday.

Künneth, W 1982. Theologie der Auferstehung. 6. Aufl. Giessen: Brunnen. (TVG.)

Lüdemann, G 1994. Die Auferstehung Jesu: Historie, Erfahrungen, Theologie. Stuttgart: Radius-Verlag.

- 1995. What really happened to Jesus: A historical approach to the resurrection, tr by John Bowden. Louisville: Westminster John Knox Press.

Marxsen, W 1975. The resurrection of Jesus of Nazareth, tr by M Kohl. Philadelphia: Fortress.

Painter, J 1987. Theology as hermeneutics: Rudolf Bultmann's interpretation of the history of Jesus. Sheffield: The Almond Press. (HTIBS.)

Pesch, R [1983] 1988. Zur Entstehung des Glaubens an die Auferstehung Jesu: Ein neuer Versuch, in Hoffmann 1988:228-255.

Robinson, J A T 1984. Rudolf Bultmann: A view from England, in Jaspert, B (Hrsg), Rudolf Bultmanns Werk und Wirkung, 149-154. Darmstadt: Wissenschaftliche Buchgesellschaft.

Schmithals, W 1967. Die Theologie Rudolf Bultmanns: Eine Einführung. 2.durchges. Aufl. Tübingen: Mohr.

Wilckens, U [1963] 1988. Der Ursprung der Überlieferung der Erscheinungen des Auferstandenen: Zur traditionsgeschichtlichen Analyse von 1. Kor. 15,1-11, in Hoffmann 1988:139-193. 